\title{
Fortification of sweet potato progenies for enhanced root dry matter and micro-nutrient density through genetic recombination
}

\author{
Nwankwo I. I. M. ${ }^{*}$, Nwaigwe G. 0. ${ }^{1}$, Aguwa U. 0. ${ }^{1}$, Okereke A. C. ${ }^{2}$ and Amanze N. J. ${ }^{1}$ \\ ${ }^{1}$ National Root Crops Research Institute, Umudike, P. M. B 7006, Umuahia. Abia State, Nigeria. \\ 2Department of Agronomy, Michael Okpara University of Agriculture, Umudike, Umuahia, Abia State, Nigeria. \\ Corresponding author. Email: nwankwomaxwell@yahoo.com; Tel: +2348063668433.
}

Copyright @ 2019 Nwankwo et al. This article remains permanently open access under the terms of the Creative Commons Attribution License 4.0, which permits unrestricted use, distribution, and reproduction in any medium, provided the original work is properly cited.

Received 2nd May, 2019; Accepted 26th June, 2019

\begin{abstract}
Experiment was conducted in the rainforest agro-eco-zone of Southeastern Nigeria under rain fed condition at the sweet potato breeding ground of National Root Crops Research Institute, Umudike, Nigeria to generate 10,000 botanical seeds for further evaluation for high root yield, dry matter and micro-nutrient content, to identify high flowering parent(s) and to select compatible parent(s) for further genetic recombination. The treatment which consisted of 14 parents of bi-parental crossing was laid out in a randomized complete block design with seven parents, each per plot per block and replicated three times while the other seven parents were maintained in different plots as pollen donors. Data collected were on: total number of emerged flowers visually counted, total number of flowers covered, total number of flowers pollinated, total number of capsules formed, total number of flowers aborted, total number of seeds obtained from crosses, number of good seeds, number of unfilled seeds, percentage of good seeds. Data collected were statistically analyzed using Statistical Package for Social Sciences (SPSS, version 15.0). Differences between means were tested using analysis of variance (ANOVA) while means separation was done using standard error of difference means at $5 \%$ probability. The results obtained showed that despite the seemingly high total number of flowers produced from the controlled crosses (14520), only $17.4 \%$ of this figure yielded good seeds. The objective of realizing 10,000 botanical seeds through the hand pollination was not achieved as a result of high flower abortion arising probably from moisture stress which was severe during seed filling. The variety Tio-joe gave the highest flower production of 2334 . The relatively high number of capsules of 347obtained from the cross between UMUSPO 3 and NRSP/2 indicated high compatibility between the two parents which suggested that the two parents could be used for further recombination for micro-nutrient enhancement.
\end{abstract}

Keywords: Capsules, flowers, hand pollination, seeds, sweet potato.

\section{INTRODUCTION}

The crop sweet potato (Ipomoea batatas) is an important security food crop in many areas of sub-Saharan Africa. According to $\mathrm{FAO}$ (2004), sweet potato crop is grown in an estimated 4.1 million hectares, with about 9.9 million tons of root production (CIP, 1999). However, Since the introduction of Sweet potato (Ipomoea batatas) into Nigeria over 200 years ago, its high yield, wide adaptability, tolerance of abiotic stresses, and versatility have contributed to its traditional and continuing importance in
Nigerian agriculture. The sweet potato crop ranked fourth after cassava, yam, and cocoyam among the organization of root and tuber crops in planted area. The Nigerian annual sweet potato production of about 5.2 million metric tonnes grown in about 1.2 million hectares with mean yields of 3.5t/ha is lower than those in other parts of the world such as China and Japan, and this is a cause for concern to breeders and farmers. In Nigeria, the crop is mostly used for food and livestock feed with only $5 \%$ of 
total production going for industrial starch extraction and food processing. However, high dry matter and high starch content is becoming more important for starch production. Most Nigerian sweet potato landraces have low or moderate dry matter (DM) content less than $30 \%$. Over the past 30 years the national breeding programme in the country have worked to increase the DM content and micro-nutrient density with little progress. As a result of the lack of progress, there appears to be a need for controlled hand pollination to concentrate these essential ingredients and to broaden the genetic diversity of the sweet potato crop.

A number of cultivars have emerged from the farmers' field due to selection pressure by farmers and as a result of environmental changes new genotypes developed through controlled hybridization need to replace these sweet potato landraces (Nwankwo et al., 2018). These cultivars possess tolerance of biotic stresses and resistance to abiotic stresses and these are still grown in small areas in sweet potato growing States in Nigeria. However, these genotypes are equally low in root yield, pests and diseases attack, and poor adaptability when planted away from their place of origin. This has been a serious challenge to the expansion of the area under sweet potato cultivation in Nigeria.

Sweet potato being the preferred staple food in some State in Nigeria, the elastic demand is constrained by inadequate production and losses in storage. The most important biotic constraints are pests such as weevils, nematodes and viruses (Mukasa et al., 2003), and leafspot diseases. Sweet potato cultivation has high environmental impact because it is usually planted in sole or in mixture as intercrop with other crops. Root production of sweet potato has the advantage of not requiring stakes. This makes it an easy crop to cultivate in comparison with yam. Sweet potato productivity is negatively impacted by declining soil fertility, diseases and pests associated with intensive cropping systems of the farmers. The crop itself is low in micro-nutrient content. Genetic improvement can contribute significantly to addressing these challenges and seizing opportunities for expanding the markets for the commodity. Important traits for breeding include high root yield per unit area, root quality and conformation, resistance/tolerance to diseases (especially sweet potato virus and leafspot diseases), weevil and nematodes. Increasing the food quality by enhancing the dry matter content especially for the orange fleshed varieties (OFSP) and micro-nutrient content. However, sweet potato breeding is very challenging, because of the genetic erosion associated with the nature of the crop, poor seed set, and incompatibility within the varieties. Limited breeding technologies also contributed to the limited accelerated breeding of sweet potato crops unlike cassava and other clonal propagated crops. Declining yields caused by declining soil fertility, pest such as weevil and diseases like sweet potato virus diseases has led to the continuous search and the development of varieties that combine disease resistance with high root yield and culinary quality as reported by Amadi et al. (2015). Various methods have been employed in sweet potato improvement. This include the collection, evaluation and selecting from the local germplasm, introduction of exotic varieties from outside the country, mutation induction of existing varieties and hybridization of the local or imported cultivars from other parts of the world and evaluating them under local conditions.

Conventional hybridization is still the principal approach for sweet potato breeding in Nigeria. Through this approach, some new cultivars developed were bred with the introgression of genes from wild species of sweet potato. Again, postharvest processing of sweet potato through value addition has become an important way for farmers to increase their income. This requires a highyielding sweet potato genotype which are high in dry matter (DM) content and micro-nutrient density. Existing sweet potato varieties in the country do not meet these demands. Therefore, disease resistant varieties with high starch and high DM yield and high micro-nutrient density are needed.

This proposed breeding work purposed to increase sweet potato productivity whilst reducing production costs and environmental impact by developing and deploying end-users preferred varieties with higher yield, greater resistance to pests and diseases and improved roots and vine quality plus high micro-nutrient density and high dry matter content. Hybridization blocks which contained biparental controlled crosses were established each with 14 parents of known traits to recombine their qualities to enhance the micronutrients of their progenies in order to obtain consumer preferred nutrient contents such as enhanced vitamin $A$, iron and high dry matter content. The parents in the hybridization blocks were crossed with the following key objectives for working towards this vision are: to generate 10,000 botanical seeds for further evaluation (for high root yield, high dry matter and micro-nutrient content), to identify high flowering parent(s) and to select compatible parent(s) for further genetic recombination.

\section{MATERIALS AND METHODS}

The experiment was conducted in the rainforest agro-ecozone of Southeastern Nigeria under rain fed condition. The sweet potato breeding ground of National Root Crops Research Institute, Umudike, Nigeria was used. The area was slashed, ploughed, harrowed and ridged before being marked into plots and the plots grouped into replications. The plot size was $3 \mathrm{~m} \times 3 \mathrm{~m}$ or $9 \mathrm{~m}^{2}$ and demarcated 1.0 $\mathrm{m}$ from another plot. Each replication had a distance of 1.0 $\mathrm{m}$.

\section{Soil analysis and climatic factors}

The soils of the experimental areas were analyzed at the 
soil laboratory of NRCRI - Umudike using the method of Jackson (1998). A composite soil sample was collected and analyzed for the physical and chemical properties of soil. The essence of analyzing the soil was to make sure that the soil does not have high Nitrogen status which should increase luxuriant vegetative growth and delays flower production and seed set. Also collected were the climatic data.

\section{Experimental design}

The treatment which consisted of 14 parents of bi-parental crossing was laid out in a randomized complete block design replicated three times. The parents were selected based on high root yield, high dry matter (DM) content of between 28 to $39 \%$, starch content of 18 to $22 \%$, high carotenoid content of 15 to $20.8 \mathrm{ug} / \mathrm{gFW}$, adaptability to poor soils and compatibility with other cultivars. Seven of the parents were planted each in a plot at a planting space of $30 \mathrm{~cm}$ by $100 \mathrm{~cm}$ within plants and inter row spacing. There were spacing of $1.0 \mathrm{~m}$ between plots, giving a plant population of 30 plants per plot and seven parents per block and replicated three times. The other seven parents were maintained in different plots for pollen collection.

Before planting, the area was sprayed with primextra, a pre-emergence herbicide to delay weed emergence which may seriously interfere with the early growth of the sweet potato crop. Further weeding was complemented with manual hoe weeding throughout the duration of the experiment.

The crossing block was established at the first week of August to make sure that blossoming took place toward dry period. This was to avoid wet period which seriously interfere with hand pollination and decreases flowering. Again, to further enhance flowering and ease of pollination, the sweet potato plants in all the plots were staked using pyramidal type of staking. No fertilizer or organic manure was applied so that the sweet potato plants do not grow luxuriantly which may delay flowering.

\section{Data collection}

The following data were collected: all emerged flowers from 15.00 hours to 17.00 hours were visually counted and recorded. Also, the following data were visually counted and recorded: total number of flowers covered, total number of flowers pollinated, total number of capsules formed, total number of flowers aborted, total number of seeds obtained from crosses, number of good seeds, number of unfilled seeds, percentage of good seeds.

\section{Data analyses}

Data collected were statistically analyzed using Statistical
Package for Social Sciences (SPSS, version 15.0). Differences between means in each genotypes were tested using analysis of variance (ANOVA), while means separation was done using standard error of difference means at $5 \%$ probability when the analysis of variance indicated significant differences in the means. A significance level of $p<0.01$ and $p<0.05$ were used throughout the study.

\section{RESULTS AND DISCUSSION}

\section{Environmental factors}

The factors of the environment such as indicated in the climatic data on rainfall, sunshine, relative humidity and air temperature during the cropping seasons indicated that the total rainfall for 2017 was $2060.80 \mathrm{~mm}$ distributed over 127 days. This decreased in 2018. Total rainfall in 2018 was $1916.10 \mathrm{~mm}$ distributed over 137 days. Monthly average maximum air temperature and relative humidity in 2018 were $32^{\circ} \mathrm{C}$ and $80.6 \%$ respectively while the monthly average minimum air temperature and relative humidity in 2017 were $31.8^{\circ} \mathrm{C}$ and $81.67 \%$ respectively. There was more sunshine in 2017 (59.70 hours) than in 2018 (56.20 hours). This result indicated climate variation for the two years (Table 1). These climatic variations might had strong influence on flower production of the varieties.

The soil samples from each plot were collected from a depth of 0 to $30 \mathrm{~cm}$ and bulked into a composite sample and used for the determination of the physical and chemical properties of the soil. The soils of the experimental sites were classified as ultisoil (FDALR, 1989). The data of the physio-chemical property of the soil of the experimental sites is presented in Table 2. The results of the soil analysis showed that the soils were sandy in texture (57\% sand in 2017 and $52 \%$ sand in 2018) in both sites, but it falls under sandy loam in soil textural classification. The current $\mathrm{pH}$ result seems to be slightly acidic (pH 5.07 in 2017 site and pH 6.08 in 2018 site). The previous land history of the two sites and analysis indicated that the soils were under Panicum maximum mixed with Mimosa pundica for two years.

The soil test result before planting showed that the exchangeable cation $\left(\mathrm{Mg}^{2+}, \mathrm{Ca}^{2+} \mathrm{K}^{+}\right.$, and $\left.\mathrm{Na}^{2+}\right)$ was in the range of high availability to plants (Landon, 1991) (Table 2). The available phosphorus of the soil fell under the range of moderately to low potassium availability. However, the result showed that total Nitrogen and Organic Carbon contents of the soil were low. This finding further signifies that although the soil requires external application of nutrients to enable the crops express their genetic potential in growth and root yield of the crop. However, application of fertilizer especially Nitrogen fertilizer will make the sweet potato crop to grow vegetative in the expense of flower production. This will be detrimental to the objective of this work which is flower 
Table 1. Climatic data for 2017 and 2018.

\begin{tabular}{lccccccc}
\hline \multirow{2}{*}{ Month } & \multicolumn{2}{c}{ Rainfall $(\mathbf{m m})$} & \multicolumn{2}{c}{ Temperature $\left({ }^{\circ} \mathbf{C}\right)$} & Relative humidity \% & $\begin{array}{c}\text { Sunshine } \\
\text { (Hrs) }\end{array}$ \\
\cline { 2 - 4 } 2017 & Amount & Day & Max & Min & $\mathbf{0 9 0 0}$ & $\mathbf{1 5 0 0}$ & \\
January & & & & & & & \\
February & 62.8 & 2 & 33 & 23 & 74 & 49 & 5.6 \\
March & 62.8 & 4 & 34 & 24 & 79 & 55 & 6.0 \\
April & 47.8 & 4 & 34 & 24 & 78 & 56 & 4.6 \\
May & 100.5 & 12 & 33 & 23 & 78 & 62 & 5.1 \\
June & 416.2 & 15 & 33 & 23 & 80 & 70 & 5.7 \\
July & 236.7 & 14 & 31 & 23 & 83 & 72 & 4.5 \\
August & 306.3 & 18 & 30 & 22 & 87 & 78 & 3.2 \\
September & 287.4 & 19 & 29 & 23 & 88 & 78 & 2.3 \\
October & 205.5 & 18 & 30 & 22 & 86 & 72 & 3.7 \\
November & 311.1 & 14 & 31 & 23 & 82 & 72 & 4.9 \\
December & 23.7 & 7 & 32 & 22 & 74 & 58 & 6.5 \\
Total & 0.0 & 0 & 34 & 22 & 78 & 53 & 7.6 \\
& 2060 & 127 & 384 & 251 & 967 & 713.62 & 59.70 \\
2018 & & & & & & & \\
January & & & & & & & \\
February & 0 & 0 & 35 & 23 & 72 & 45 & 6.4 \\
March & 78.2 & 4 & 35 & 24 & 73 & 50 & 6.3 \\
April & 34.1 & 3 & 34 & 24 & 77 & 53 & 3.9 \\
May & 129.0 & 11 & 34 & 24 & 76 & 59 & 6.1 \\
June & 138.5 & 14 & 32 & 24 & 84 & 70 & 5.0 \\
July & 427 & 22 & 30 & 24 & 87 & 77 & 3.5 \\
August & 310.2 & 17 & 30 & 23 & 86 & 75 & 3.4 \\
September & 376.7 & 19 & 29 & 23 & 88 & 78 & 2.2 \\
October & 303.3 & 19 & 29 & 23 & 88 & 76 & 2.9 \\
November & 34.9 & 21 & 30 & 23 & 86 & 78 & 4.1 \\
December & 77.8 & 6 & 31 & 23 & 87 & 71 & 4.9 \\
Total & 6.4 & 1 & 33 & 22 & 76 & 49 & 7.5 \\
\hline & 1916.1 & 137 & 382 & 280 & 980 & 781 & 56.20 \\
\hline
\end{tabular}

production. Lack of adequate soil nutrients puts the crop in a hard condition. The crop sensing danger will be forced to produce flowers before dying. It is a natural way of flower induction in sweet potato. The Physical and chemical properties of the soil at the experimental sites in 2017 and 2018 are presented in Table 2.

\section{Number of flowers formed}

The results of the total number of flowers and number of flowers produced per parent per month are presented in Table 3. High significant $(p<0.01)$ variability existed in the number of flowers produced by each of the sweet potato parents selected for the hybridization trial. The Total number of sweet potato flowers produced ranged from 1627 (by the parent TIS87/0087) to as high as 2334 (produced by Tio-jeo). A total of 14520 flowers were produced by all the parents with a mean of 2074.3 per parent. If all the high number of flowers produced were all converted into capsules and well filled seeds, perhaps a large number of seeds would have been produced which would have been of immense importance in screening for progenies with enhanced micro-nutrient and high dry matter content. High seed number and well filled capsules are the major traits for evaluating for progenies with high micro-nutrient and high dry matter content hence the genetic recombination (Nwankwo, 2008).

Table 3 shows the mean number of flowers collected per month. The mean number of flowers collected six weeks after planting at the first month ranged from 42.2 per parent with a total of 298 flowers at the first month. Flowering increased linearly up to 5691 at the 4th month with a mean of 813.0 and then sharply decreased to 3896 at the 5th month with a mean of 556.6 flowers. The sharp decrease may be as a result of drastic reduction in soil moisture which became noticeable at the 5th month. This affected the flower production. For example, although there were longer hours of sunshine hours compared with other months in both years, however, there was no rainfall 
Table 2. Physical and chemical properties of the soil at the experimental sites in 2017 and 2018.

\begin{tabular}{lcc}
\hline Soil elements & 2017 Values & 2018 Values \\
\hline Sand \% & 57.0 & 52.40 \\
Silt \% & 31.5 & 22.80 \\
Clay \% & 12.0 & 24.80 \\
pH $\left(\mathrm{H}_{2} 0\right) 1: 2: 5$ & 5.58 & 5.45 \\
Bray - 2P (PPM) & 32.0 & 20.40 \\
Organic carbon \% & 0.37 & 0.99 \\
Organic matter \% & 0.61 & 1.70 \\
Nitrogen \% & 0.03 & 0.098 \\
EA (M eg/100g soil) & 0.3 & 3.52 \\
K (M eg/100g soil) & 0.16 & 0.14 \\
Na (M eg/100g soil) & 0.14 & 0.209 \\
Ca (M eg/100g soil) & 3.05 & 3.60 \\
Mg (M eg/100 soil) & 2.35 & 1.60 \\
ECEC & 5.862 & 9.069 \\
BS\% & 75.56 & 61.19 \\
Textural class & Sandy loam & Sandy clay loam \\
\hline
\end{tabular}

Note: soil depth $30 \mathrm{~cm}$.

Table 3. Number of flowers produced per parent per month.

\begin{tabular}{lcccccc}
\hline \multirow{2}{*}{ Parents } & 1st month & 2nd month & 3rd month & 4th month & 5th month & $\begin{array}{c}\text { Total number of } \\
\text { flowers produced }\end{array}$ \\
\cline { 2 - 6 } & Sept. & Oct. & Nov. & Dec. & Jan. 2019 & 2260 \\
Solo 1 & 28 & 205 & 430 & 910 & 687 & 2334 \\
Tio-joe & 46 & 213 & 422 & 1048 & 605 & 2204 \\
Umuspo/3 & 58 & 308 & 570 & 717 & 611 & 2089 \\
NRSP/4 & 32 & 294 & 462 & 712 & 589 & 1819 \\
NRSP/45 & 21 & 241 & 301 & 775 & 481 & 1627 \\
TIS87/0087 & 44 & 296 & 283 & 603 & 401 & 2187 \\
NRSP/1 & 69 & 332 & 338 & 926 & 522 & 14520 \\
Total & 298 & 1889 & 2746 & 5691 & 3896 & 2074.3 \\
Mean & 42.6 & 269.9 & 392.3 & 813.0 & 556.6 & $1627-2334$ \\
Range & $28-69$ & $205-332$ & $283-510$ & $603-1048$ & $401-687$ & $=$ \\
Sig. level & $p<0.01$ & $p<0.01$ & $p<0.01$ & $p<0.01$ & $p<0.01$ & $=$ \\
LSD (0.05) & 7.0 & 17.4 & 21.4 & 30.8 & 25.5 & \\
\hline
\end{tabular}

throughout the days of the month of December in 2017 and in 2018, the month of December received minimal rainfall of $6.4 \mathrm{~mm}$ for only one day which was not even adequate to sustain the flower production of the sweet potato varieties and the comprehensive performance of the sweet potato crop in general. Okonkwo (1985) and Orkwor (2000) in their works on yam hybridization reported that moisture is very critical in seed formation and could cause abortion of flowers in yam. Sweet potato being a root crop may suffer the same soil dehydration problem. Again, the variability in flower yield among the varieties could mainly be related to soil type, temperature and soil moisture conditions, during the growing period, which was also suggested by Sameh et al. (2011).
However, the flowering of the parents increased gradually and linearly. As the parents increased in age, and there was enough moisture in the soil, flowering increased. However, with the increase in water stress, vegetative senescence set in, thereby forcefully decreasing flower emergence and gradual death of the sweet potato plants as shown in Figure 1.

\section{Number of flowers, capsules and seeds produced}

Table 4 shows the result of total number of flowers produced, number of flowers covered, number of flowers pollinated and total number of capsules formed after 


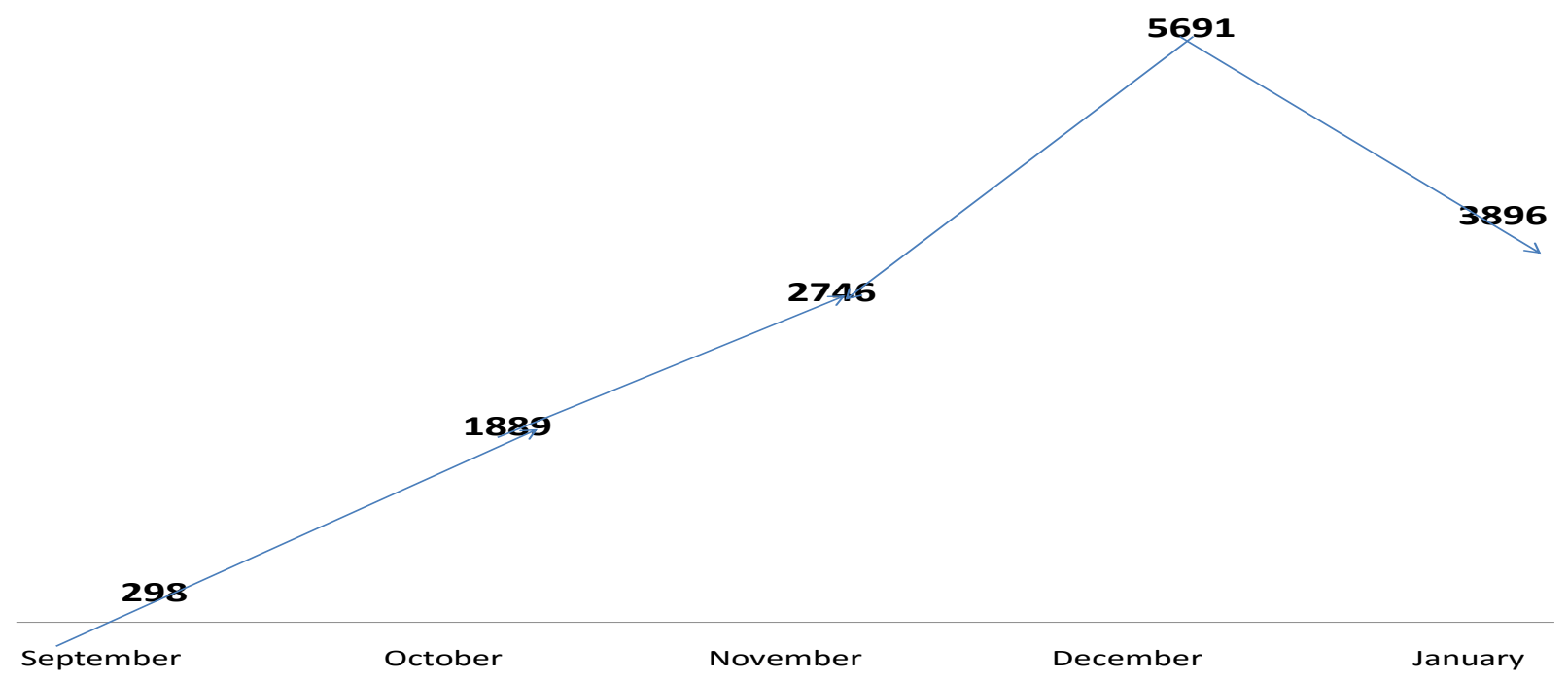

Figure 1. Number of capsules produced per parent per month.

Table 4. Total number of flowers produced, Number of flowers covered, number aborted and number of capsules formed.

\begin{tabular}{lcccccc}
\hline Parents & $\begin{array}{c}\text { Total number } \\
\text { of flowers } \\
\text { produced }\end{array}$ & $\begin{array}{c}\text { Number of } \\
\text { flowers } \\
\text { covered }\end{array}$ & $\begin{array}{c}\text { Number of } \\
\text { flowers } \\
\text { pollinated }\end{array}$ & $\begin{array}{c}\text { Number } \\
\text { of flowers } \\
\text { aborted }\end{array}$ & $\begin{array}{c}\text { Total number } \\
\text { of capsules } \\
\text { formed }\end{array}$ & $\begin{array}{c}\text { Total } \\
\text { number } \\
\text { of seeds }\end{array}$ \\
\hline Solo 1xTio-joe & 2260 & 482 & 415 & 67 & 310 & 615 \\
Tio-joe x NRSP/1 & 2334 & 422 & 312 & 110 & 300 & 909 \\
Umuspo/3x NRSP/2 & 2204 & 417 & 382 & 35 & 347 & 695 \\
NRSP/4 x Tio-joe & 2089 & 329 & 220 & 109 & 210 & 395 \\
NRSP/45 x UMUSPO/3 & 1819 & 318 & 200 & 118 & 196 & 498 \\
TIS87/0087 x Tio-joe & 1627 & 510 & 445 & 65 & 316 & 718 \\
NRSP/1 x Tio-joe & 2187 & 386 & 312 & 74 & 248 & 529 \\
Total & 14520 & 2864 & 2291 & 573 & 1927 & 4359 \\
Mean & 2074.2 & 409.1 & 377.3 & 81.9 & 275.3 & 622.7 \\
Range & $1627-2334$ & $318-510$ & $200-445$ & $35-118$ & $196-347$ & $395-909$ \\
Sig.level & $p<0.01$ & $p<0.01$ & $p<0.01$ & $p<0.01$ & $p<0.01$ & $p<0.01$ \\
LSD $(0.05)$ & 49.2 & 21.8 & 19.5 & 9.8 & 17.9 & $=$ \\
\hline
\end{tabular}

crossing. The result indicated high significant $(p<0.01)$ variation in the number of flowers covered, number of flowers pollinated and total number of capsules formed from various families. However, out of the total number of 14520 flowers produced from various families, a total number of 2864 flowers were covered to prevent natural pollination by insects, and a total number of 2291 flowers were hand pollinated. A total number of 573 flowers were aborted after hand pollination while a total of number of 1927 flowers resulted into capsules. The total number of botanical seeds that resulted from the crosses was 4359 . This number of seeds would be used for seedling evaluation to select genotypes for enhanced micronutrient content and dry matter content. Gasura et al. (2008) reported that flowering ability is an essential aspect in sweet potato breeding since it determines the potential of improving certain cultivars through breeding and evaluation of progenies.

\section{Seed production}

The results of the total number of seeds produced, number of good seeds, number of unfilled seeds and percentage of good seeds from each of the parents crossed are presented in Table 5. The result indicated high significant variability in the number of seeds produced by the sweet potato parents pollinated. Total number of seeds produced by the parents varied from 395 seeds (from the cross between NRSP/4 and Tio-joe) to 909 seeds (from the cross between Tio-joe and NRSP/1). A total number of 4359 seeds were produced with grand mean of 622.7 seeds. 
Table 5. Total number of seeds, number of good seeds, number of unfilled seeds, percentage of good seeds and weight of 100 seeds from hand pollinated flowers.

\begin{tabular}{lccccc}
\hline Parents & $\begin{array}{c}\text { Total number of } \\
\text { seeds produced }\end{array}$ & $\begin{array}{c}\text { Number of } \\
\text { good seeds }\end{array}$ & $\begin{array}{c}\text { Number of } \\
\text { unfilled seeds }\end{array}$ & $\begin{array}{c}\text { Percentage } \\
\text { good seeds }\end{array}$ & $\begin{array}{c}\text { Total number } \\
\text { of seeds }\end{array}$ \\
\hline Solo 1xTio-joe & 615 & 411 & 204 & 67.0 & 615 \\
Tio-joe x NRSP/1 & 909 & 439 & 470 & 48.2 & 909 \\
Umuspo/3x NRSP/2 & 695 & 317 & 378 & 52.0 & 695 \\
NRSP/4 x Tio-joe & 395 & 212 & 183 & 54.0 & 395 \\
NRSP/45 x UMUSPO/3 & 498 & 319 & 129 & 64.0 & 498 \\
TIS87/0087 x Tio-joe & 718 & 425 & 293 & 59.0 & 718 \\
NRSP/1 x Tio-joe & 529 & 402 & 127 & 76.0 & 529 \\
Total & 4359 & 2525 & 1834 & - & 4359 \\
Mean & 622.7 & 360.7 & 262 & 60.0 & 622.7 \\
Range & $395-909$ & $212-439$ & $127-470$ & $48-76$ & $395-909$ \\
Sig.level & $p<0.01$ & $p<0.01$ & $p<0.01$ & - & $P<0.01$ \\
LSD $(0.05)$ & 27.0 & 20.5 & 17.5 & - & $=$ \\
\hline
\end{tabular}

Out of a total of 2525 good seeds produced, the highest number of 439 representing about $17.4 \%$ of the total good seed produced was from the cross between the parents Tio-joe and NRSP/ 1 while the least number of good seeds of $212(8.4 \%$ of all good seeds produced) were obtained from the cross between the parents NRSP/4 and Tio-joe. The higher percentage of good seeds $(54.0 \%)$ produced by parents NRSP/4 and Tio-joe relative to the parents of Tio-joe and NRSP/1 (48.2\%) can be attributed to the higher number of flower production and number of flowers that were receptive in the former than in the later. It could also be attributed to time of pollination, pollen and stigma fertility and receptivity. Number of unfilled seeds ranged from 127 from the cross between the parents NRSP/1 and Tio-joe to 470 s seed from the cross between the parents of Tio-joe and NRSP/1 giving a total of 1834 unfilled seeds with mean of 262 unfilled seeds. However, the large number of unfilled seeds may be as a result of lack of rainfall and no irrigation. Most of the seeds collected during those periods were not filled but favored flowering up to a point when flowering declined (Table 1).

Tester and Langridge, (2010) reported that plant breeding aim at developing better varieties and to achieve this aim, extensive breeding programs are conducted to produce seeds which are evaluated as seedlings to select genotypes which manifested increased yield and superior quality of the crop grown from the new varieties. As Nwankwo et al. (2019) observed, making these seeds available and developing them into seedlings would help to identify high-yielding cultivars with enhanced micronutrient density that are adapted to their local conditions. It would also be possible to increase sweet potato production and also widen the genetic base so that national breeding programmes can utilize the promising cultivars in the hybridization programmes to transfer the desirable characteristics to the progenies. According to IRETA (1991), breeding cultivars through sexual hybridization indicated that crosses would be evaluated and selected, first under local conditions in on-station and on-farm trials and then in national collaborative trials in the various agro-ecological zones of the country. High yielding pathogen-tested promising clones would be sent for official documentation and release to farmers later. A number of different clones having desirable attributes would be used for further crossing, to have progenies with as widely different combinations of characters as possible.

\section{Conclusion}

Despite the seemingly high total number of flowers produced from controlled crosses (14520), only $17.4 \%$ of this figure yielded good seeds. The objective of realizing 10,000 botanical seeds through hand pollination was not achieved as a result of high flower abortion arising probably from moisture stress which was severe during seed filling. The variety Tio-joe gave the highest flower production of 2334 . The relatively high number of capsules of 347obtained from the cross between the parents UMUSPO/3 and NRSP/2 indicated high compatibility between the two parents suggesting that the two parents could be used for further recombination for micro-nutrient enhancement. The seedling progenies resulting from the number of good seeds obtained would be evaluated for enhanced root dry matter and micro-nutrient density. It also recommended that since dry season planting of sweet potato enhances flowering, irrigation should be employed to prolong the lifespan of the crop and to enhance seed filling which will in addition increase the seed weight of the various families.

\section{CONFLICT OF INTEREST}

The authors declare that there is no conflict of interest. 


\section{REFERENCES}

Amadi, C. O., Onyeka, J., Chukwu, G. O., \& Okoye, B. C. (2015). Hybridization and Seed Germination of Taro (Colocasia Esculenta) in Nigeria. Journal of Crop Improvement, 29(1), 106-116.

FAO (2004). FAO statistics. Food and Agricultural Organization of the United Nations, Rome, Italy.

FDALR (1985). Federal Department of Agriculture and Land Resources. Reconnaissance Soil. Survey of Imo State, Nigeria. Soils report FDALRS Kaduna Nigeria.

Gasura, E., Mashingaidze, A. B., \& Mukasa, S. B. (2008). Genetic variability for tuber yield, quality, and virus disease complex traits in Uganda sweet potato Germplasm. African Crop Science Journal, 16(2), 147-160.

International Potato Center (CIP) (1999). Annual Report. International Potato Center, Lima, Peru.

IRETA (1991). Root Crop Breeding and Improvement. Annual Research Report of the Institute for Research Extension and Training in Agriculture and the School of Agriculture. University of the South Pacific, Alafua. Pp. 1-12.

Jackson, J. (1998). Cassava and their associated characteristics. Malaysian Agricultural Research and Development Institute Bulletin, 8, 54-59.

Landon J. R. (1991). Booker tropical soil manual: A handbook for soil survey and Agricultural land evaluation in the tropics and sub-tropics. Longman Scientific and Technical, Essex. New York. P. 474.

Mukasa, S. B., Rubaihayo, P. R., \& Valkonen, J. P. (2003). Incidence of viruses and virus like diseases of sweet potato in Uganda. Plant Disease, 87(4), 329-335.

Nwankwo, I. I. M (2008). M.Sc. Project Thesis on "Studies on morphological characteristics, flowering intensity and Tuber yield in intra-specific hybrids of white yam (Dioscorea rotundata Poir)" submitted to College of crop and soil sciences. Michael Okpara university of Agriculture, Umudike Umuahia Abia State. Nigeria.
Nwankwo, I. I. M., Akinbo, O. K., Ikoro, A. I., Orji, N. A. C., \& Njoku, T. C. (2018). Evaluation of selected sweet potato landraces for high harvest index and high root yield indices for parental selection. International Journal of Agricultural Policy and Research, 6(7), 90-97.

Nwankwo, I. I. M., Opara, E. C. Akinbo, O. K., Obasi, C. P., \& Njoku, T.C. (2019). Evaluation of flower yield, seed production and effect of time on the genetic recombination of sweet potato Parents in the Rainforest Agro-Eco-Zone of Umudike Southeastern Nigeria. SSRG International Journal of Agriculture \& Environmental Science (SSRG-IJAES), 6(3).

Okonkwo, S. N. C. (1985). The botany of the yam plant, and its exploitation in enhanced productivity of the crop. In Advances in yam research. The biochemistry and Technology of the yam tuber. G.C Osuji (ed). Biochemical Society of Nigeria and Anambra state University of Technology, Enugu Nigeria. Pp. 4-31.

Orkwor, G. C., Asiedu, R., \& Ekanayake, I. K. eds (2000). Food Yams: Advances in Research IITA and NRCRI - Nigeria INTEC Printers, Ibadan, Nigeria. Pp. 63-70.

Sameh, A. M. M., Hala, A. A., \& Nashwa, I. A. (2011). Stability study of sweet potato yield and its component characters under different environments by joint regression analysis. Journal of Horticultural Science and Ornamental Plants, 3(1), 43-54.

Tester, M., \& Langridge, P. (2010). Breeding technologies to increase crop production in a changing world. American Association for the Advancement of Science, 327(5967), 818822. 